\title{
Natural Fibre Polymer Composites - A game changer for the aviation sector?
}

\author{
Alejandra Gomez-Campos ${ }^{1 *}$, Claire Vialle ${ }^{1 *}$, Antoine Rouilly ${ }^{1}$, Lorie Hamelin ${ }^{2}$, Aline Rogeon ${ }^{3}$, David Hardy ${ }^{3}$, \\ Caroline Sablayrolles ${ }^{1}$ \\ ${ }^{1}$ Laboratoire de Chimie Agro-industrielle, LCA, Université de Toulouse, INRAE, Toulouse, France \\ ${ }^{2}$ Toulouse Biotechnology Institute (TBI), INSA, INRAE UMR792 and CNRS UMR5504, Federal University of Toulouse, 135 \\ Avenue de Rangueil, F-31077, Toulouse, France \\ ${ }^{3}$ VESO Concept, 1620 Route de Bellevue, F-31530, Merenvielle, France \\ *Corresponding authors (alejandra.gomezcampos@ensiacet.fr / claire.vialle@toulouse-inp.fr)
}

This is a non-peer review preprint submitted to Preprints.org. This manuscript has been submitted for publication in the Journal of Cleaner Production. Please note that, despite having undergone peerreview, the manuscript has yet to be formally accepted for publication. Subsequent versions of this manuscript may have slightly different content. 


\title{
Natural Fibre Polymer Composites - A game changer for the aviation sector?
}

\author{
Alejandra Gomez-Campos ${ }^{1 *}$, Claire Vialle ${ }^{1 *}$, Antoine Rouilly ${ }^{1}$, Lorie Hamelin ${ }^{2}$, Aline Rogeon ${ }^{3}$, David Hardy ${ }^{3}$, \\ Caroline Sablayrolles ${ }^{1}$ \\ ${ }^{1}$ Laboratoire de Chimie Agro-industrielle, LCA, Université de Toulouse, INRAE, Toulouse, France \\ ${ }^{2}$ Toulouse Biotechnology Institute (TBI), INSA, INRAE UMR792 and CNRS UMR5504, Federal University of Toulouse, 135 \\ Avenue de Rangueil, F-31077, Toulouse, France \\ ${ }^{3}$ VESO Concept, 1620 Route de Bellevue, F-31530, Merenvielle, France \\ *Corresponding authors (alejandra.gomezcampos@ensiacet.fr / claire.vialle@toulouse-inp.fr)
}

\section{KEY WORDS}

Life Cycle Assessment; Bio-based materials; Flax fibre; Climate change; Aviation; Interior fittings

\begin{abstract}
As part of the efforts to reduce the environmental impacts caused by the aviation sector, the use of bio-based instead of fossil-based materials has been assessed as a possible mitigation option. Natural Fibre Polymer Composites have proven to have a higher environmental performance in the automotive sector and are emerging as an option for weight reduction in aircraft. This study quantifies, though Life Cycle Assessment, the environmental performance of specific flax-based composite panels intended for aircrafts as interior fitting elements (i.e. partition panels, tray tables, baggage compartments) compared to a glass fibre/epoxy composite with a honeycomb core. Through system expansion, the fate of co-products issued from the production of the flax fibre technical textile used as reinforcement in the biocomposite material were considered in the assessment.
\end{abstract}

Results showed that for an application in the aeronautics sector, the weight of the panels is the upmost critical parameter shaping the overall environmental performance of panels. Focusing on the panel production only, the biocomposite panel showed a higher environmental performance in the categories of climate change and marine eutrophication compared to the conventional panel, and the fire suppressant agent was identified as the main contributor to the environmental impacts of the biobased panel. Yet these gains were negligible when considering the full life cycle of the panels, due to the higher weight (14\%) of the bio-based panels; which is linked to the bio-based panel being at a prototype stage.

In order to improve the environmental performance of the biocomposite panel and thus reduce its weight, it was shown relevant to optimize geometry of the panel itself, especially its core, so less resin could be used.

\section{INTRODUCTION}

Though it only represents a little over $2 \%$ of greenhouse gas (GHG) emissions from fossil fuels use (Graver et al. 2019), aviation is becoming a growing public concern in the light of the current climate urgency (IPCC 2018). Because fuel represents ca. 25\% of operating expenses (IATA 2019), efforts to reduce fuel consumption have already been undertaken by the sector. In 2011, the European Commission, through the Advisory Council for Aviation Research and Innovation in Europe (ACARE), published five goals to be achieved in the Flightpath 2050 report. One of these goals targets a $75 \%$ reduction in $\mathrm{CO}_{2}$ emissions and a $90 \%$ reduction in $\mathrm{NO}_{x}$ emissions per passenger kilometre, while another goal aims for aircrafts to be recyclable (ACARE 2011).

In an attempt to achieve these goals, lighter materials have been researched to replace currently used ones. Weight reduction of aircrafts translates into a reduction of GHG emissions; the jet fuel used 
during an aircraft lifetime is in fact responsible for more than $75 \%$ of the $\mathrm{GH}$ emissions in the whole life cycle (Bachmann et al. 2017). Moreover, these GHG emissions are more environmentally damaging compared to those emitted at ground level due to the increased interaction of gases at higher altitudes (IPCC 1999).

Given the lower density of natural fibres compared to glass fibres, different authors have extensively reviewed the use of natural fibres as reinforcement in composite materials (Ticoalu et al. 2010; Faruk et al. 2012; Mohammed et al. 2015; Hristian et al. 2016; Peças et al. 2018; Sanjay et al. 2018). Among the various natural fibres that have been used as reinforcement, flax represented $50 \%$ of the market share for composites in 2012 (Barth and Carus 2015) and comes fourth in production out of the different commercially major fibre sources (Faruk et al. 2012). To date, the main industrial application for natural fibre reinforced composites remains the automotive sector (Deng and Tian 2015; Joshi et al. 2004; Le Duigou and Baley 2014; Yan et al. 2014; Fernando et al. 2015) as well as their use as construction materials or leisure products/consumer goods (C.E.L.C. 2020).

Through Life Cycle Assessment (LCA), Natural Fibre Polymer Composites (NFPC) have been demonstrated to have higher environmental performance when used in the automotive industry (Joshi et al. 2004; Le Duigou and Baley 2014), mainly due to the lower density of natural fibres; which translates into lower emissions resulting from fuel combustion. The potential application of these type of composites in the aviation sector has been addressed in the work of Bachmann et al. (2017), Vieira and Bravo (2016) \& Vidal et al. (2018).

While these studies are valuable contributions in understanding the overall environmental performance and drawbacks of these materials, they suffer from limitations. Among others, these studies do not detail how the various co-products generated through the production of the flax fibre (i.e. short fibres, seeds, shives, and flakes) are used and traded in the market. At best, simple allocation techniques are applied where past (or hypothetical) economical values (e.g. Vidal et al. 2018) or weights (e.g. Le Duigou and Baley 2014) are used to divide the overall environmental impact between the desired products (composite material) and its various co-products. Other studies do not even document if co-products are generated nor the exact inventory data that are considered (e.g. Vieira and Bravo 2016). The study of Deng and Tian (2015) is a notable exception where an effort to document the actual co-products fate was made, but it suffers from a major misunderstanding of the agricultural phase of the feedstock. In fact, the authors considered flax in the same way as when it is cultivated for seed production. Yet, when flax is intended for textile production, it is harvested at a much later stage where the stem has reached full maturity but the seeds remaining are of lower quality and quantity. In the specific case of applications for the aviation sector, detailed life cycle inventories are scarce as pointed out in the review of Bachmann et al. (2017). Moreover, existing life cycle results are given for a rather limited number of impact categories, essentially focusing on cumulative energy demand and greenhouse gas emissions (e.g. Vieira and Brave 2016; Vidal et al. 2018).

In an endeavour to bridge this gaps, this study presents a complete Life Cycle Assessment to confirm the environmental relevance of flax fibre reinforced composites, compared to their current market competitors, in the aeronautics sector. The vision is to uncover potential trade-offs among the various environmental impacts. Moreover, it explores the relevance of bio-based materials as a viable option for reducing the environmental impacts caused by the aviation sector.

\section{MATERIALS AND METHODS}

\subsection{Environmental Assessment Method}


The full environmental impact of the panels was quantified through a LCA following a consequential approach (Brandão et al. 2017; Earles and Halog 2011; Weidema et al. 2018).

The LCA carried out herein is considered consequential in the sense that no co-product is left outside the system boundaries and their fate is taken into consideration as part of the environmental performance of the final product. This approach follows ISO 14040:2006 and ISO 14044:2006 recommendations and aims to reflect the intended and non-intended environmental consequences of decision-making. Furthermore, it strives to only take into account marginal processes and suppliers, i.e. those reacting to a demand change (Hamelin 2013; Brandão et al. 2017).

\subsection{Goal and Scope definition}

This study takes its point of departure from a real-case where a SME (small and medium enterprise) is developing a sandwich panel with a novel core structure that aims to substitute the current materials used in the interior design of airplanes (i.e. partition panels, tray tables, baggage compartments).

The specific prototype panel developed by this SME represents the biocomposite panel studied herein. The prototype is an omega core sandwich panel (Figure 1), made entirely out of a flax fibre reinforced composite with an epoxy matrix. This includes both the skins and the core. The goal is to compare the environmental performance of the biocomposite panel with the performance of a conventional panel with skins made out of glass fibre reinforced composite (with an epoxy resin) and a honeycomb core in aramid fibre paper.

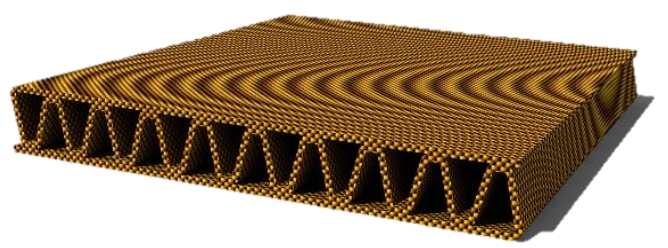

Figure 1. Omega core sandwich panel structure. Image from CORDIS website (EC 2018).

The production and transformation process of flax fibre into the technical textile is carried out in France. For both panels, the specific origin of the rest of the raw materials not being specified, global processes where preferred. As specific distances between production sites is unknown, "market for" data was used as it includes transportation values. Production of the biocomposite panel is carried out in France.

The conventional panel used as reference is similar to panels commercialized under the name NORBOND ${ }^{\circledR}$. Technical characteristics of the NORBOND ${ }^{\circledR}$ panel were used as reference for values and production was considered to be carried out in France. Therefore, a French electricity mix was used.

The functional unit was defined as the use of $1 \mathrm{~m}^{2}$ of sandwich panel as secondary structures (interior fitting elements) in the interior of an airplane A320 NEO with a lifespan of 30 years.

The evaluation was carried out with SimaPro 8.5.2 software.

\subsection{Life Cycle Inventory Analysis}

The life cycle inventory $(\mathrm{LCl})$ data relate to the inputs and outputs from the different life cycle stages of the panels (foreground data) were obtained directly from the SME producing the panel. When the 
needed LCl data could not be obtained from the company, data were collected from scientific literature. Background data (e.g. electricity production) were obtained from $\mathrm{LCl}$ databases, namely Ecoinvent v3.4. The exact $\mathrm{LCl}$ data considered are here detailed and grouped per life cycle stage, namely (i) raw material, (ii) production; (iii) use and (iv) end-of-life.

\subsubsection{Raw Materials}

Materials from the sandwich panels are classified into two main components: skins and core. The skins and core of the biocomposite panel are made from the same materials: flax fibre technical textile as reinforcement, an epoxy resin as the binding agent, methylamine as the hardening agent and ammonium polyphosphate as the flame retardant agent.

In contrast, the skins and core of the conventional panel are made from different materials. The skins are made from glass fibre, epoxy resin, methylamine and decaBDE (Decabromodiphenyl ether) as the flame retardant agent. The core of the conventional panel is a commonly used structure know as honeycomb, made of aramid fibre paper dipped in a phenolic resin. Table 1 details the composition of $1 \mathrm{~m}^{2}$ of each of the panels assessed. A detailed description of how these values were calculated can be found in the Supporting Information (SI-1.1 and SI-1.2).

Table 1. Material composition of $1 \mathrm{~m}^{2}$ of aircraft panel

\begin{tabular}{|l|l|c|c|}
\hline \multirow{4}{*}{ Structure } & \multicolumn{1}{|c|}{ Material } & $\begin{array}{c}\text { Biocomposite } \\
\text { panel }\end{array}$ & $\begin{array}{c}\text { Conventional } \\
\text { panel }\end{array}$ \\
\cline { 3 - 4 } & & \multicolumn{2}{|c|}{$\mathrm{kg} / \mathrm{m}^{2}$} \\
\hline \multirow{5}{*}{ Skins } & Epoxy resin & 0.55 & 0.55 \\
\cline { 2 - 4 } & Methylamine (hardener) & 0.19 & 0.12 \\
\cline { 2 - 4 } & APP (flame retardant) & 0.34 & \\
\cline { 2 - 4 } & decaBDE (flame retardant) & & 0.10 \\
\cline { 2 - 4 } & Flax fibre technical textile & 0.72 & 1.16 \\
\cline { 2 - 4 } & Glass fibre & & \\
\hline \multirow{5}{*}{ Core } & Epoxy resin & 0.41 & \\
\cline { 2 - 4 } & Methylamine (hardener) & 0.15 & \\
\cline { 2 - 4 } & APP (flame retardant) & 0.25 & 0.55 \\
\cline { 2 - 4 } & Flax fibre technical textile & 0.54 & $\mathbf{2 . 5 8}$ \\
\cline { 2 - 4 } & Aramid fibre & & $\mathbf{3 . 1 5 *}$ \\
\cline { 2 - 4 } & Phenolic resin & & \\
\hline
\end{tabular}

*Calculated value. The real mass value of the biocomposite panel is considered $3 \mathrm{~kg} / \mathrm{m}^{2}$, as experimentally proved, for future calculations.

For the production of the biocomposite panel, a commercial polymeric matrix was used. The chemical composition of the polymeric matrix (which comprises the epoxy resin, the hardening agent and the flame retardant agent) was experimentally determined to better identify the major components and their proportions, as described in the SI (SI-1.3). Mass quantities were obtained through calculations described in the $\mathrm{SI}$ and sum up to a total mass of $3.15 \mathrm{~kg} / \mathrm{m}^{2}$. However, the mass of the biocomposite was experimentally measured to be $3 \mathrm{~kg} / \mathrm{m}^{2}$. This value was kept and used throughout the study.

Components of the conventional panel were based on the technical datasheet provided by the and on the work of Vidal et al. (2018). The conventional panel considered in the work of Vidal et al. (2018) uses a phenolic resin as the polymeric matrix. In this case, however, the technical datasheet of the conventional panel selected, specifies the polymeric matrix to be an epoxy resin. The technical 
datasheet gives an average weight of the NORBOND ${ }^{\circledR}$ panel of $2.58 \mathrm{~kg} / \mathrm{m}^{2}$, the proportion of the components of the conventional panel in Vidal et al. (2018) were used to quantify its materials (refer to $\mathrm{SI}-2)$.

The life cycle inventory for each of the materials presented in Table 1 is summarized in Table 2. 
Table 2. LCl data for the Raw Materials life cycle stage

\begin{tabular}{|c|c|c|c|}
\hline Material & LCl source data & Ecoinvent process used, when relevant & Comments \\
\hline Epoxy resin & Ecoinvent v3.4 & $\begin{array}{l}\text { Epoxy resin }\{G L O\} \mid \text { market for epoxy resin | } \\
\text { Conseq, } U\end{array}$ & $\begin{array}{l}\text { The commercial polymeric resin used for the production of the } \\
\text { biocomposite panel, contains the flame retardant agent. From the } \\
\text { chemical analysis carried out for the commercial resin (detailed in } \\
\text { the SI-1.3), a } 1.63 \text { epoxy/flame retardant ratio was determined. }\end{array}$ \\
\hline $\begin{array}{l}\text { Ammonium } \\
\text { Polyphosphate (APP) }\end{array}$ & Ecoinvent v3.4 & $\begin{array}{l}\text { Nitrogen fertiliser, as } \mathrm{N}\{\mathrm{RER}\} \mid \\
\text { monoammonium phosphate production | } \\
\text { APOS, } \mathrm{U} \\
\text { (Used as proxy with modifications) }\end{array}$ & $\begin{array}{l}\text { Since no consequential process were available, the one mentioned } \\
\text { herein was used as starting point and adjusted with consequential } \\
\text { data. A detailed description of the modifications is available in the } \\
\text { SI-1.4. }\end{array}$ \\
\hline $\begin{array}{l}\text { Decabromodiphenyl } \\
\text { ether (decaBDE) }\end{array}$ & Ecoinvent v3.4 & $\begin{array}{l}\text { Decabromodiphenyl ether }\{\text { GLO }\} \mid \text { market for } \\
\text { decabromodiphenyl ether | Conseq, } U\end{array}$ & $\begin{array}{l}\text { From Vidal et al. (2018), the flame retardant agent used in the } \\
\text { conventional panel is identified as decaBDE. }\end{array}$ \\
\hline Methylamine & Ecoinvent 3.4 & $\begin{array}{l}\text { Methylamine }\{\text { GLO }\} \mid \text { market for | Conseq, U } \\
\text { (Used as proxy) }\end{array}$ & $\begin{array}{l}\text { From the chemical analysis of the commercial hardener used for } \\
\text { the biocomposite panel (detailed in the SI-1.3), three main } \\
\text { substances were identified: isophorone diamine, alkylether } \\
\text { polyamine and methylamine. } \\
\text { Only the production of methylamine is present in the Ecoinvent } \\
\text { database. As the toxicity of the three molecules is highly similar, } \\
\text { this process was used as proxy. }\end{array}$ \\
\hline $\begin{array}{l}\text { Flax fibre technical } \\
\text { textile }\end{array}$ & $\begin{array}{l}\text { Gomez-Campos } \\
\text { et al. } \\
\text { (Unpublished } \\
\text { results) }\end{array}$ & Flax fibre technical textile $\{F R\} \mid$ Conseq & $\begin{array}{l}\text { This dataset comprises all activities from the agricultural phase to } \\
\text { the weaving of the textile, and includes land use changes. The } \\
\text { complete } \mathrm{LCl} \text { used for the creation of the flax fiber technical textile } \\
\text { production process is available in the SI Excel document (SI-2). }\end{array}$ \\
\hline Glass fibre & Ecoinvent v3.4 & Glass fibre $\{G L O\} \mid$ market for | Conseq, $U$ & \\
\hline Aramid fibre & Ecoinvent v3.4 & $\begin{array}{l}\text { Nylon 6-6 }\{\text { GLO }\} \text { | market for | Conseq, } U \\
\text { (Used as proxy) }\end{array}$ & $\begin{array}{l}\text { The most commonly used material in honeycomb core structures is } \\
\text { known as NOMEX (Morton-Jones and Ellis 1986) and is described as } \\
\text { a type of nylon. } \\
\text { Based on this and on literature work involving the production of } \\
\text { aramid fibre (Wilhelm 2018), the production process of nylon was } \\
\text { used as a proxy for aramid fibre production. }\end{array}$ \\
\hline Phenolic resin & Ecoinvent v3.4 & Phenolic resin $\{G L O\} \mid$ market for | Conseq, $U$ & \\
\hline
\end{tabular}




\subsubsection{Production}

The production stages of manufacturing of $1 \mathrm{~m}^{2}$ of biocomposite panel are shown in Figure 2.

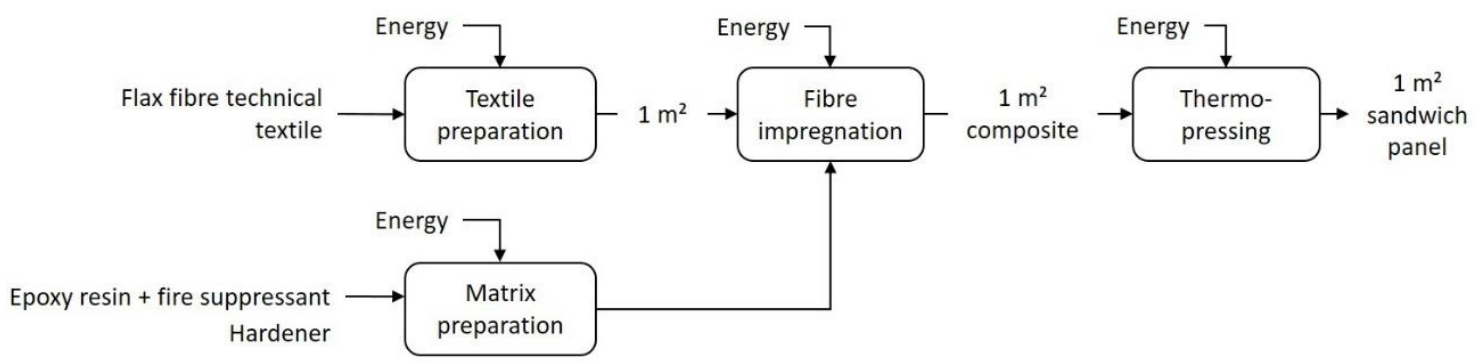

Figure 2. Biocomposite panel manufacture process

Data on electricity consumption were estimated directly from the prototype's production process by the manufacturer and are presented in Table 3. No losses are considered so no waste is produced.

Table 3. Manufacturing process of $1 \mathrm{~m}^{2}$ of the biocomposite panel

\begin{tabular}{|l|c|}
\hline \multicolumn{1}{|c|}{ Production stage } & $\begin{array}{c}\text { Energy consumption } \\
\left(\mathbf{W h} / \mathbf{m}^{\mathbf{2}} \mathbf{)}\right.\end{array}$ \\
\hline Textile preparation & Considered negligible \\
\hline Matrix preparation & 15 \\
\hline Fibre impregnation & 160 \\
\hline Thermo-pressing & 525 \\
\hline TOTAL & $\mathbf{7 0 0}$ \\
\hline
\end{tabular}

The manufacture of the conventional panel was based on the production process described by Vidal et al. (2018). In their work, the authors take into consideration the application of a decorative film at the end of the process. To ensure comparability with the biocomposite panel, this step was not included in the system boundaries of this study nor waste issued during production. Figure 3 shows the manufacturing process of $1 \mathrm{~m}^{2}$ of conventional panel.

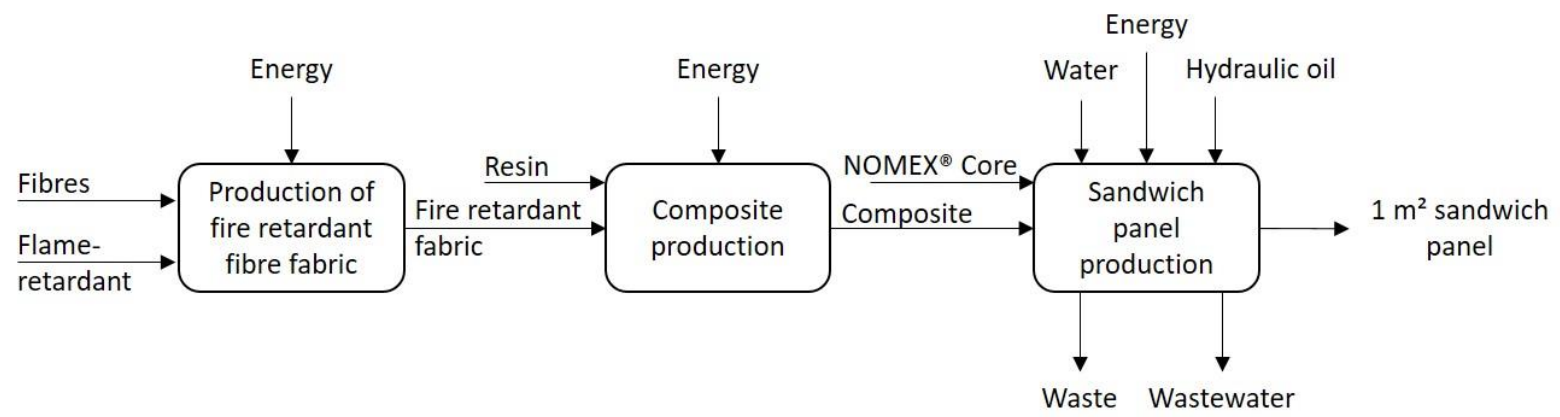

Figure 3. Conventional panel manufacture process

Data for the inputs for the production stage of the conventional were obtained from the work of Vidal et al. (2018). In total, the production of $1 \mathrm{~m}^{2}$ of conventional panel requires $16 \mathrm{kWh}(\approx 57.6 \mathrm{MJ}$ as defined in the original source) of electricity, $0.0082 \mathrm{~kg}$ of hydraulic oil and $0.9 \mathrm{~kg}$ of water. From the work of Vidal et al. (2018), it is understood that the energy consumption value comprises the production of the honeycomb core and the moulding of the conventional panel itself.

The life cycle inventory for the processes considered in the production of both panels is summarized in Table 4. 
Table 4. $\mathrm{LCl}$ data for the Production life cycle stage

\begin{tabular}{|l|c|l|l|}
\hline \multicolumn{1}{|c|}{ Process } & $\begin{array}{c}\text { LCl source } \\
\text { data }\end{array}$ & $\begin{array}{c}\text { Ecoinvent process used, } \\
\text { when relevant }\end{array}$ & \multicolumn{1}{c|}{ Comments } \\
\hline $\begin{array}{l}\text { Electricity production } \\
\text { (biocomposite panel) }\end{array}$ & $\begin{array}{c}\text { Ecoinvent } \\
\text { v3.4 }\end{array}$ & $\begin{array}{l}\text { Electricity, medium voltage } \\
\{\text { FR | market for | Conseq, } U\end{array}$ & $\begin{array}{l}\text { The production of the } \\
\text { biocomposite panel is } \\
\text { carried out in France. }\end{array}$ \\
\hline $\begin{array}{l}\text { Electricity production } \\
\text { (conventional panel) }\end{array}$ & $\begin{array}{c}\text { Ecoinvent } \\
\text { v3.4 }\end{array}$ & $\begin{array}{l}\text { Electricity, medium voltage } \\
\{\text { FR | market for | Conseq, } U\end{array}$ & $\begin{array}{l}\text { The conventional panel is } \\
\text { considered to be carried out } \\
\text { in France. }\end{array}$ \\
\hline $\begin{array}{l}\text { Hydraulic oil } \\
\text { (conventional panel) }\end{array}$ & $\begin{array}{c}\text { Ecoinvent } \\
\text { v3.4 }\end{array}$ & $\begin{array}{l}\text { Lubricating oil }\{\text { RoW\}| market } \\
\text { for lubricating oil | Conseq, } U\end{array}$ & \\
\hline $\begin{array}{l}\text { Water } \\
\text { (conventional panel) }\end{array}$ & Substances & $\begin{array}{l}\text { Water, process, unspecified } \\
\text { natural origin/kg }\end{array}$ & \\
\hline
\end{tabular}

\subsubsection{Use}

The use of the panels is related to the operation of the aircraft and more specifically, to fuel consumption as it is directly linked to the total mass of the aircraft. To evaluate the environmental performance of the panel, an aircraft A320neo was modelled. Technical data from the aircraft (Table 5) was recovered from the SME producing the biocomposite panel as well as from the specifications given by Scandinavian Airlines about their air fleet (SAS 2019), which includes A320neo aircrafts. The lifespan of the interior fitting elements (i.e. partition panels, toilet doors / walls, baggage compartments, service tables, etc.) for which the panels will be used is the same as the airplane itself as there is typically replacement of these elements over the plane lifespan. Throughout their lifetime, aircrafts are considered to have a kilometric performance of $5.59 \times 10^{7} \mathrm{~km}$ (Maibach et al., 1999).

Table 5. Aircraft specifications considered in this study

\begin{tabular}{|l|l|l|}
\hline \multicolumn{1}{|c|}{ Specification } & \multicolumn{1}{c|}{ Value } & \multicolumn{1}{c|}{ Source } \\
\hline Aircraft & A320neo & Project partner \\
\hline Aircraft lifespan & 30 years & Project partner \\
\hline Aircraft max. take-off weight & $77 \mathrm{t}$ & Project partner / SAS 2019 \\
\hline Interior design elements' weight & $10 \mathrm{t}$ & Project partner \\
\hline Range & $4600 \mathrm{~km}$ & SAS 2019 \\
\hline Seats & 174 & SAS 2019 \\
\hline Fuel (kerosene) consumption & $0.025 \mathrm{l} /$ seat km & SAS 2019 \\
\hline
\end{tabular}

The range of the aircraft makes it possible to assume that it will be used for intracontinental flights within Europe. The "Transport, passenger, aircraft $\{R E R\} \mid$ intracontinental | Conseq, U" process from the Ecoinvent v3.4 database was therefore taken as reference for the estimation of direct emissions linked to the kerosene consumption on a medium haul aircraft. The kilograms of kerosene consumed per $\mathrm{m}^{2}$ of panel per the lifetime of the aircraft $(\mathrm{KCP})$ were calculated through the following equation:

$K C P=\frac{F C * \text { Seats } * k m P * M p * \rho_{\text {kerosene }}}{W} \quad$ Equation 1

where $\mathrm{FC}$ is the aircraft fuel consumption, $\mathrm{kmP}$ represents the kilometric performance, $\mathrm{Mp}$ is the mass of the panel, $\rho_{\text {kerosene }}$ is kerosene's density, and $W$ is the interior design elements' weight. 


\subsubsection{End-of-Life}

Following the French Environment \& Energy Management (ADEME) legislation on waste (article R5478 of the environmental code) (ADEME 2018), a product is considered as dangerous waste if they present one or more of the following characteristics: Explosive (H1), Oxidizer ( $\mathrm{H} 2)$, Highly flammable (H3-A), Flammable (H3-B), Irritating (H4), Harmful (H5), Toxic (H6), Carcinogenic (H7), Corrosive (H8), Infectious (H9), Toxic for reproduction (H10), Mutagenic (H11), Substances and preparations which, in contact with water, air or acid, release a toxic or very toxic gas (H12), Sensitizing agent (H13), Ecotoxic (H14), Substances and preparations which, after elimination, may make way by any means to another substance to form, for example a leachate, that has any of the characteristics previously listed (H15).

Based on this, and because of the presence of substances such as methylamine in the hardener (H14), both panels were treated as dangerous waste. The Ecoinvent v3.4 process used for the modelling of the end-of-life phase was then chosen as "Hazardous waste, for incineration \{Europe without Switzerland\}| market for hazardous waste, for incineration | Conseq, $U$ ". Incineration of the panels was chosen following the recommendations of the project's partner in the aviation industry.

Currently, some recycling facilities exist for recycling specific recyclable parts of the aircraft. However, as there is too little of these recyclable parts reaching the recycling facilities to ensure a sufficient revenue from such businesses, the innovation and improvement in this field is rather slow. For this reason, the recycling industry for aircraft panels was judged insufficiently mature to consider recycling as a feasible option for end-of-life management technique.

\subsection{Life Cycle Impact Assessment}

The European Commission established the Product Environmental Footprint (PEF) as the way to evaluate the life cycle environmental performance of a product (EC 2020). As at the time that this study was carried out, the method was still not available, the ILCD 2011 Midpoint+ method (Figure 4) was chosen to evaluate the environmental impacts of the panels. This method was chosen as it is the most recently developed and similar to the methodology followed by the PEF. In order to be as close to the PEF method as possible, the ILCD Midpoint+ method was slightly adapted to meet recent recommendations from the European Commission (PEFCR; EC 2017) based on the latest IPCC update (AR5; IPCC 2013). This affects the GWP100 of i) biogenic methane $(34 \mathrm{~kg} \mathrm{CO}$ eq); ii) non-biogenic methane ( $36.75 \mathrm{~kg} \mathrm{CO}_{2}$ eq) and iii) carbon monoxide, fossil and from land use changes (1.57 $\left.\mathrm{kg} \mathrm{CO}_{2} \mathrm{eq}\right)$. 


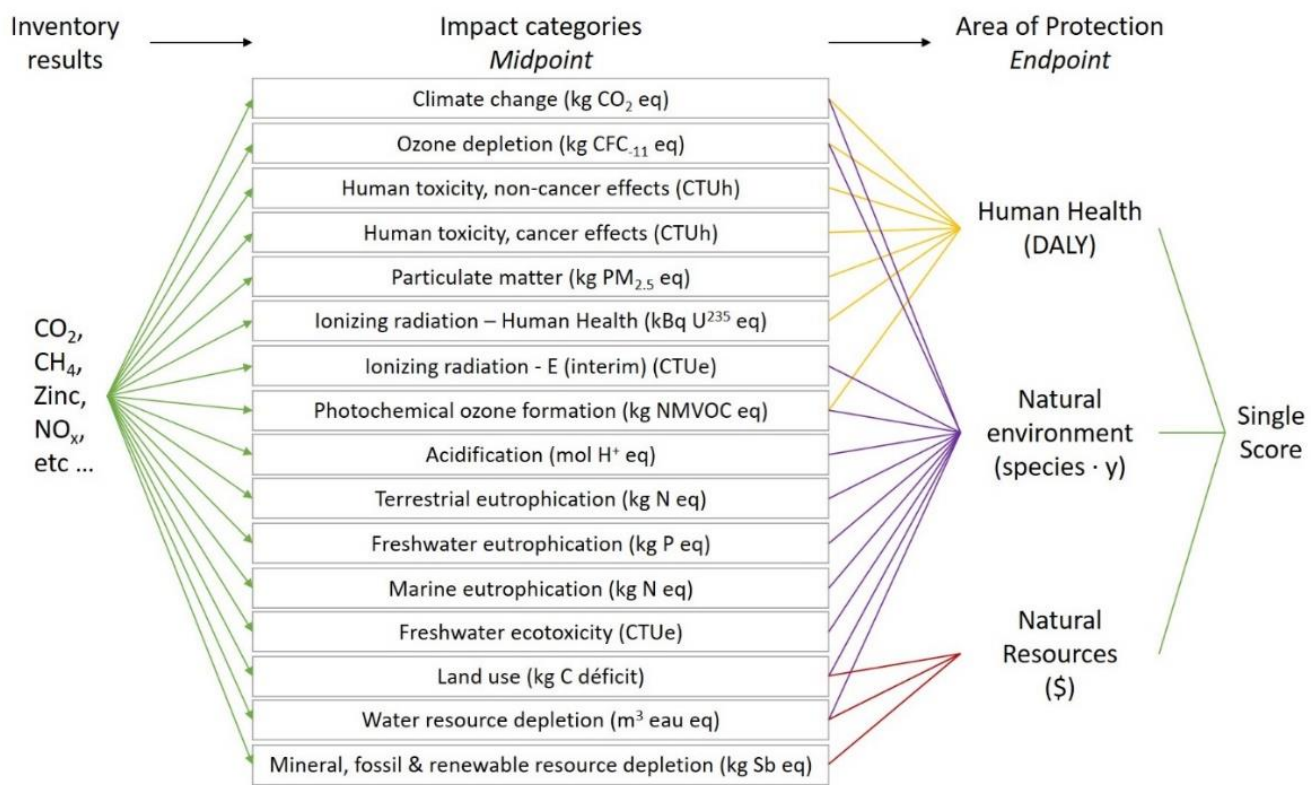

Figure 4. Representation of the ILCD 2011 Midpoint+ evaluation method

Through the environmental analysis method, the inputs and outputs of the elementary flows identified during the life cycle inventory analysis (collected data) are translated into impact indicator results. Results can be presented at midpoint, endpoint and single score levels.

As recommended by the European Commission on the use of common methods for LCAs (EC 2013), out of the 16 impact categories evaluated in the ILCD 2011 Midpoint+ method, the following impacts were chosen to be assessed: Climate change, Ozone depletion, Particulate matter formation, lonizing radiation, Photochemical ozone formation, Acidification, Freshwater eutrophication, Marine eutrophication and Mineral, fossil \& renewable resources depletion. More precisely, only impacts labelled as "category I" (i.e. the highest recommendation level) and as "category II" were considered (JRC 2011). The only exception is terrestrial eutrophication, since marine and freshwater eutrophication are already considered.

\section{RESULTS}

Results highlight that for each environmental impact studied, the environmental performance of both panels is essentially shaped by the use phase (Table 6).

Table 6. Contribution of each life cycle stage of both panels to the environmental impact categories. RM: Raw Materials; P: Production; U: Use; EOL: End-of-Life; ren. : renewable. N: Negligible.

\begin{tabular}{|c|c|c|c|c|c|c|c|c|}
\hline \multirow{2}{*}{ Impact category } & \multicolumn{4}{|c|}{ Biocomposite Panel } & \multicolumn{4}{|c|}{ Conventional Panel } \\
\hline & $\mathbf{R M}$ & $\mathbf{P}$ & U & EOL & RM & $\mathbf{P}$ & $\mathbf{U}$ & EOL \\
\hline Climate change $(\mathrm{kg} \mathrm{CO} 2 \mathrm{eq})$ & 8.26 & 0.02 & $23 \times 10^{5}$ & 7.07 & 12.54 & 0.53 & $20 \times 10^{5}$ & 6.08 \\
\hline Ozone depletion (kg CFC-11 eq) & $\mathrm{N}$ & $\mathrm{N}$ & 0.40 & $\mathrm{~N}$ & $\mathrm{~N}$ & $\mathrm{~N}$ & 0.34 & $\mathrm{~N}$ \\
\hline Particulate matter (kg PM $2.5 \mathrm{eq})$ & 0.03 & $\mathrm{~N}$ & 536 & 0.01 & $\mathrm{~N}$ & $\mathrm{~N}$ & 461 & 0.01 \\
\hline Ionizing radiation $\mathrm{HH}\left(\mathrm{kBq} \mathrm{U}_{235} \mathrm{eq}\right)$ & 0.47 & $\mathrm{~N}$ & $13 \times 10^{4}$ & -0.08 & 0.08 & 0.01 & $11 \times 10^{4}$ & -0.07 \\
\hline Photochemical ozone formation (kg NMVOC eq) & 0.05 & $\mathrm{~N}$ & $11 \times 10^{3}$ & 0.01 & 0.03 & $\mathrm{~N}$ & $9.7 \times 10^{3}$ & 0.01 \\
\hline Acidification (molc $\mathrm{H}+\mathrm{eq}$ ) & 0.06 & $\mathrm{~N}$ & $13 \times 10^{3}$ & 0.02 & 0.05 & $\mathrm{~N}$ & $11 \times 10^{3}$ & 0.02 \\
\hline Freshwater eutrophication (kg P eq) & 0.01 & $\mathrm{~N}$ & 443 & $\mathrm{~N}$ & $\mathrm{~N}$ & $\mathrm{~N}$ & 381 & $\mathrm{~N}$ \\
\hline Marine eutrophication (kg N eq) & 0.01 & $\mathrm{~N}$ & $3.9 \times 10^{3}$ & $\mathrm{~N}$ & 0.01 & $\mathrm{~N}$ & $3.4 \times 10^{3}$ & $\mathrm{~N}$ \\
\hline Mineral, fossil \& ren. resource depletion (kg Sb eq) & $\mathrm{N}$ & $\mathrm{N}$ & 4.10 & $\mathrm{~N}$ & $\mathrm{~N}$ & $\mathrm{~N}$ & 3.53 & $\mathrm{~N}$ \\
\hline
\end{tabular}


Moreover, results show that the conventional panel outperforms the biocomposite panel by $14 \%$ in all impact categories (Figure 5). This difference corresponds precisely to the mass gap between the two panels, the biocomposite panel having a higher mass than the conventional panel. This correlation is due to the fact that emissions are linked to the combustion of fuel. At the same time, fuel consumption is linked to the weight of the aircraft. The higher the mass of the aircraft, the higher the fuel consumption level and, therefore, the amount of emissions produced. As in this case the Use Phase is the main contributor for both the panels, the mass difference translates directly into the difference of impact between them.

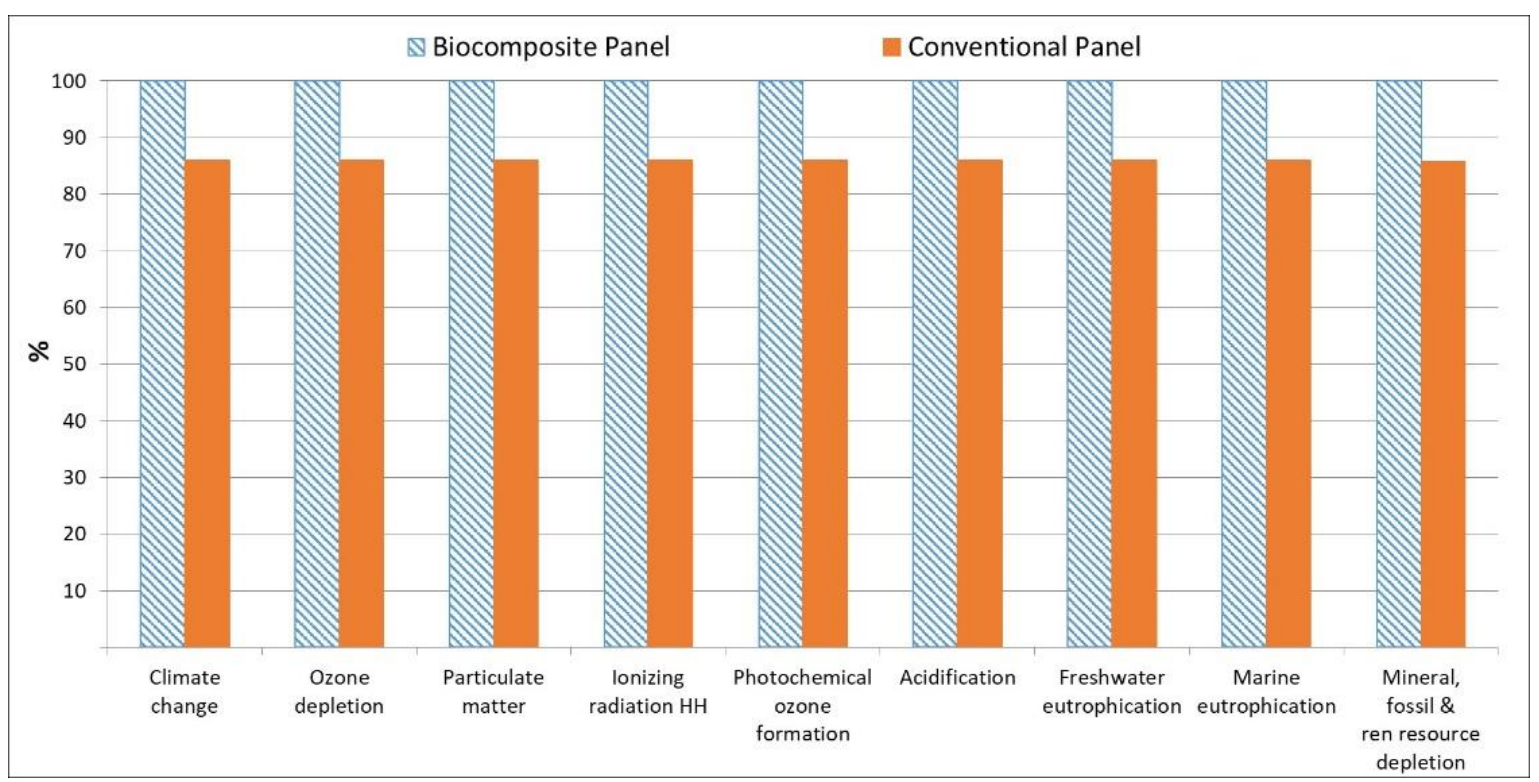

Figure 5. Comparison of the environmental performance of a biocomposite and a conventional panel from a cradle-to-grave perspective

Figure 5 shows the performance of panels over their whole life cycle (i.e. cradle-to-grave). By following a cradle-to-gate approach, the environmental performance of both panels was evaluated without taking into consideration the Use and End-of-Life stages of their life cycle. From this analysis, and considering all studied impact categories, the Raw Materials stage was identified to be responsible for up to $99 \%$ of the environmental impact of the biocomposite panel and over $65 \%$ for all categories for the conventional panel (Table 7).

Table 7. Contribution of each life cycle stage (in \%) of both panels to the environmental impact categories from a cradle-togate perspective.

RM: Raw Materials; P: Production; ren. : renewable.

\begin{tabular}{|l|c|c|c|c|}
\hline \multirow{2}{*}{\multicolumn{1}{|c|}{ Impact category }} & \multicolumn{2}{c|}{ Biocomposite Panel } & \multicolumn{2}{c|}{ Conventional Panel } \\
\cline { 2 - 5 } & RM & P & RM & P \\
\hline Climate change & 99.71 & 0.29 & 95.76 & 4.24 \\
\hline Ozone depletion & 99.90 & 0.10 & 95.78 & 4.22 \\
\hline Particulate matter & 99.87 & 0.13 & 83.25 & 16.75 \\
\hline lonizing radiation HH & 99.89 & 0.11 & 84.71 & 15.29 \\
\hline Photochemical ozone formation & 99.71 & 0.29 & 90.23 & 9.77 \\
\hline Acidification & 99.67 & 0.33 & 91.76 & 8.24 \\
\hline Freshwater eutrophication & 99.50 & 0.50 & 55.21 & 44.79 \\
\hline Marine eutrophication & 99.41 & 0.59 & 91.94 & 8.06 \\
\hline Mineral, fossil \& ren. resource depletion & 100.07 & -0.07 & 106 & -6.00 \\
\hline
\end{tabular}

Further analysis of the raw materials of both panels showed that for the biocomposite panel, the flame retardant agent and the production of the flax fibre technical textile are the main contributors to the studied environmental impacts (Figure 6). On the other hand, glass fibre and aramid fibre production 
are the main contributors to the environmental impacts of the conventional panel, followed by the flame retardant agent and the epoxy resin production (Figure 7).

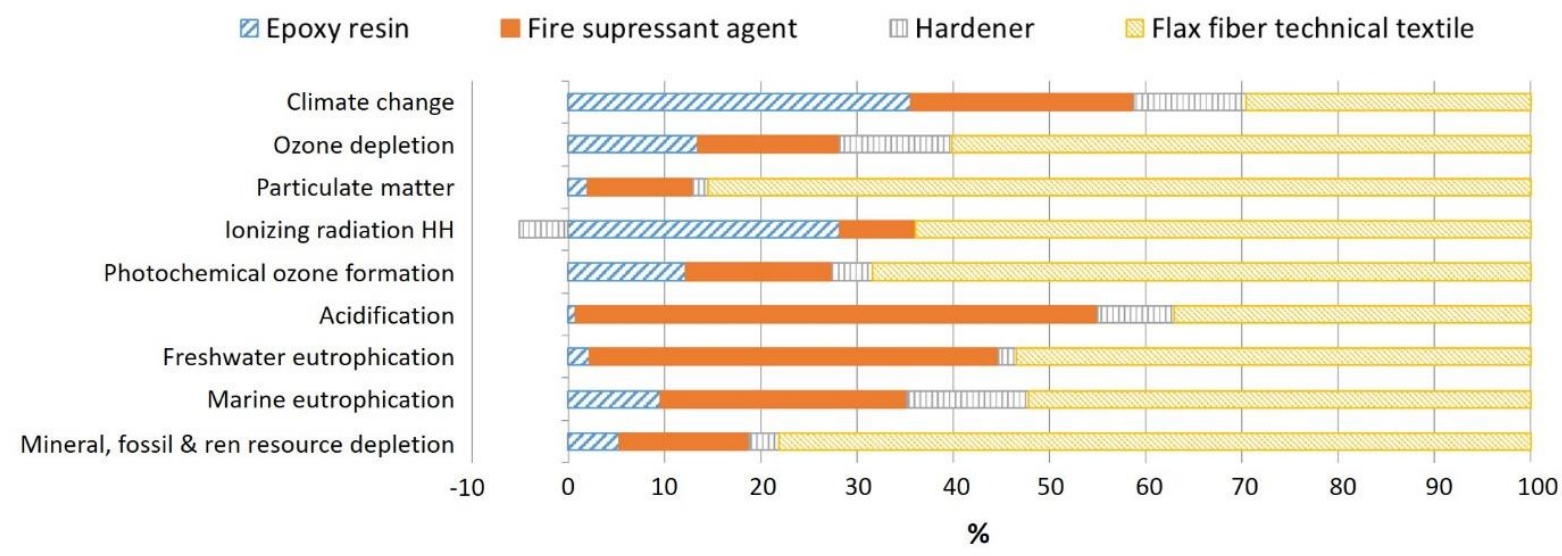

Figure 6. Contribution of the raw materials to the potential environmental impact of the biocomposite panel

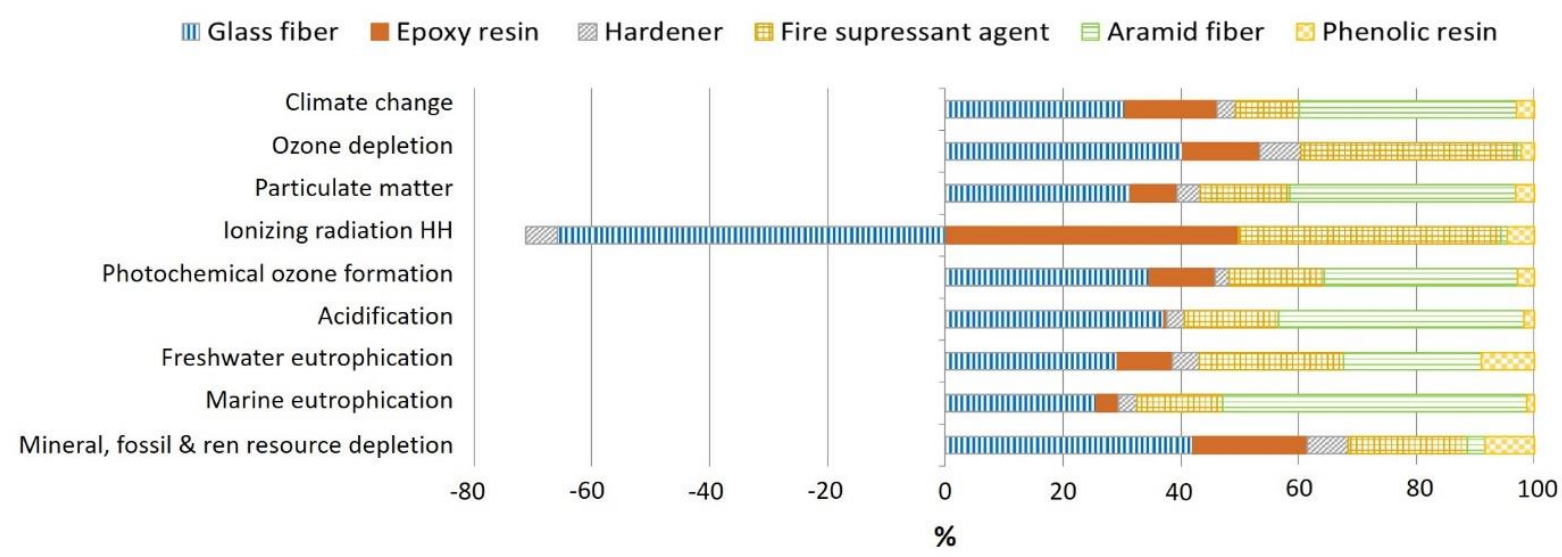

Figure 7. Contribution of the raw materials to the potential environmental impact of the conventional panel

From comparing the performance of both panels, results showed (Figure 8) that the biocomposite panel has a better performance in the environmental impact categories of Climate change and Marine eutrophication than the conventional panel. However, the conventional panel outperforms the biocomposite panel in all the other categories (Ozone depletion, Particulate matter, lonizing radiation, Photochemical ozone formation, Acidification, Freshwater eutrophication and Mineral, fossil \& renewable resources depletion). 


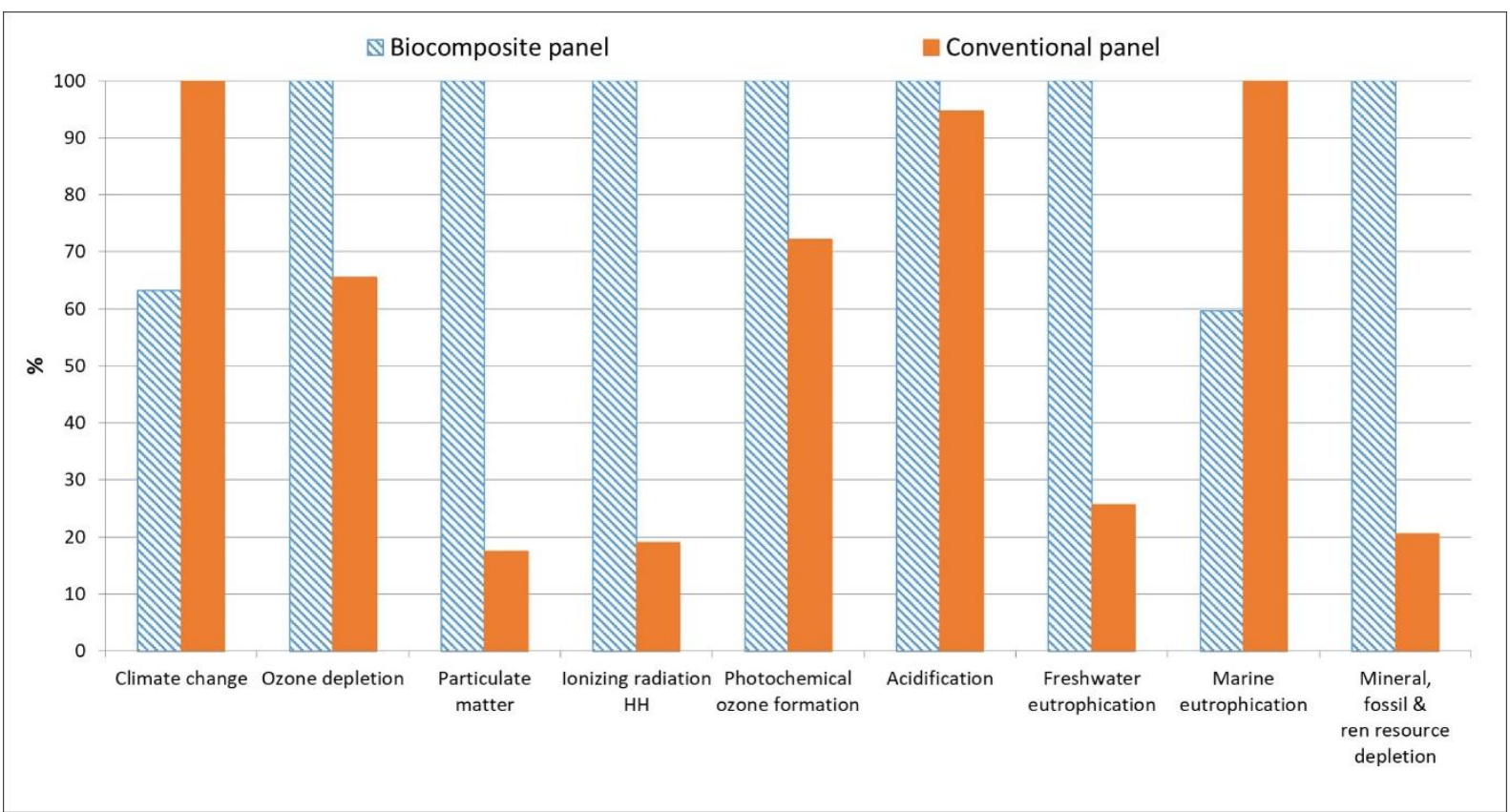

Figure 8. Comparison of the environmental performance of a biocomposite and a conventional panel from a cradle-to-gate perspective

To identify the strengths and weaknesses of the biocomposite panel, the main contributors to each of the impact categories were identified. Findings are summarized in Table 8, which presents the performance of the biocomposite panel compared to the conventional panel and the process/main contributors responsible for the potential environmental impacts for each category.

Table 8. Biocomposite panel's environmental performance relative to the conventional panel, cradle-to-gate

\begin{tabular}{|l|l|l|}
\hline \multicolumn{1}{|c|}{ Impact category } & Performance* & \multicolumn{1}{c|}{ Main contributors (biocomposite panel) } \\
\hline Climate change & $34 \%$ & $\begin{array}{l}\text { Flax fibre technical textile: Flax cultivation (-167\%)** } \\
\text { Gains are directly linked to flax culture, specifically to } \\
\text { the } \mathrm{CO}_{2} \text { captured by the plant. }\end{array}$ \\
\hline Ozone depletion & $\mathbf{2 7 \%}$ & $\begin{array}{l}\text { Flax fibre technical textile: Spinning (58\%) } \\
\text { Halons used in the coating of pipelines distributing } \\
\text { natural gas used as energy source for the spinning } \\
\text { process of the flax fibres are responsible for the } \\
\text { impacts on ozone depletion. }\end{array}$ \\
\hline Particulate matter & $\mathbf{8 4 \%}$ & $\begin{array}{l}\text { Flax fibre technical textile: Wood residues } \\
\text { combustion (80\%) } \\
\text { The valorisation of flax shives (issued from the } \\
\text { scutching step of flax fibre transformation) induces the } \\
\text { displacement of wood residues to waste (details in } \\
\text { Gomez-Campos et al., Unpublished results), which are } \\
\text { then burnt. The combustion of these wood residues } \\
\text { contribute to particulate matter formation. }\end{array}$ \\
\hline Ionizing radiation HH & $93 \%$ & $\begin{array}{l}\text { Flax fibre technical textile: Flax cultivation (62\%) } \\
\text { Epoxy resin production (35\%) } \\
\text { Electricity consumption linked to the production of the } \\
\text { epoxy resin's components as well as fertilizers used in } \\
\text { the flax cultivation stage. }\end{array}$ \\
\hline
\end{tabular}




\begin{tabular}{|l|c|l|}
\hline $\begin{array}{l}\text { Photochemical ozone } \\
\text { formation }\end{array}$ & 36\% & $\begin{array}{l}\text { Flax fibre technical textile: } \text { Flax cultivation (68\%) } \\
\text { CO emissions linked to land clearing as a result of } \\
\text { additional arable land demand. }\end{array}$ \\
\hline Acidification & $5 \%$ & $\begin{array}{l}\text { Flame retardant (51\%) } \\
\text { Flax fibre technical textile: } \text { Flax cultivation (41\%) } \\
\text { The production of phosphoric acid used for the } \\
\text { production of MAP, which is used as flame retardant } \\
\text { agent and fertilizer in the case of flax cultivation. }\end{array}$ \\
\hline $\begin{array}{l}\text { Freshwater } \\
\text { eutrophication }\end{array}$ & $\mathbf{8 0 \%}$ & $\begin{array}{l}\text { Flame retardant (49\%) } \\
\text { Flax fibre technical textile: } \text { Flax cultivation (47\%) } \\
\text { Phosphate emissions into water linked to the } \\
\text { production of phosphoric acid used for MAP synthesis, } \\
\text { which is used as flame retardant agent and fertilizer in } \\
\text { the case of flax cultivation. }\end{array}$ \\
\hline Marine eutrophication & $30 \%$ & $\begin{array}{l}\text { Flax fibre technical textile: } \text { Hay production (-141\%) } \\
\text { The valorisation of flax flakes (issued from the } \\
\text { scutching step of flax fibre transformation) as animal } \\
\text { feed reduces the amount of hay production and the } \\
\text { impacts associated to it (details in Gomez-Campos et } \\
\text { al., Unpublished results). }\end{array}$ \\
\hline $\begin{array}{l}\text { Mineral, fossil \& } \\
\text { renewable resource } \\
\text { depletion }\end{array}$ & $85 \%$ & $\begin{array}{l}\text { Flax fibre technical textile: } \text { Flax cultivation (95\%) } \\
\text { Zinc is used for treatment of seeds and soils for flax } \\
\text { cultivation. }\end{array}$ \\
\hline
\end{tabular}

*Difference on the environmental impact between the biocomposite panel and the conventional panel.

** Contribution of the mentioned process to the environmental impact.

\section{DISCUSSION}

For an application in aeronautics, the critical element of the panel is its mass as it has a direct influence on fuel consumption and therefore on the level of air emissions. This is revealed in Table 6 where the use phase is shown to represent more than $99 \%$ of the contribution to all impact categories considered in this study. This is acknowledged by previous studies; Vidal et al. (2018), for instance, estimated that the use phase represents over $98 \%$ of the contribution, although they do not present the results of this phase in their study.

This implies that for any material with an application in aeronautics, the nature of the raw materials, the efficiency of their supply chains and/or its management in end-of-life has negligible influence over their environmental performance. This means that as long as the biocomposite panel has a higher mass value than its non-bio-based counterpart, the conventional panel will always be more competitive from an environmental point of view.

Our study found that the biocomposite panel had a $14 \%$ higher mass than its counterpart. This was in part due to the fact that aviation industry imposes stringent requirements with very little manoeuvre for changes, making it challenging for the biocomposite panel to keep its expected lower weight advantage. In the present case, due to the high porosity of the flax fibre absorbing the resin, a fibre: resin:ratio of 40:60 was required instead of the originally 50:50 ratio stipulated by the resin manufacturer; which contributed to render the biocomposite material heavier.

One way to minimize the overall amount of material being used could have been through changes in the geometrical shape (defining and limiting the total height of the panel; Figure 1). Yet, this is in turn 
limited by the moulding technology available to attain the desired structure as well as the high mechanical exigencies of the sector.

Focusing on the raw materials phase only, the procurement of flame retardants proved to be one of the main contributors to the panels' environmental impacts (Figure 6 and Figure 7). However, the exigencies on flame retardancy are as well very high and allow for little flexibility for environmental improvements.

Specifically refereeing to the raw materials of the biocomposite panel, the production of the flax fibre technical textile proved to be an important contributor to its environmental impact (Figure 6). This due mainly to the agricultural activities linked to flax production and the fibre transformation step of spinning (Gomez-Campos et al., Unpublished results).

This result is consistent with recent LCA studies showing that the main processes contributing to the environmental impact of flax fibres are related to yarn production (spinning). Fernando et al. (2015), for example, report this process to be responsible for about $69-78 \%$ of the overall impact of flax fibres. The spinning step may be omitted, as e.g. in the automotive sector where randomly distributed fibres pose no problems to meet technical specifications for some components. Yet spinning is not an optional step when the fibres are intended for aviation applications as woven fibres offer superior mechanical properties (Deng et al. 2016). Therefore, once again, it is really important to look beyond the fibre itself; as even though natural fibre production has a lower impact than glass fibre production (Joshi et al. 2004), this affirmation is dependent on the natural fibre transformation processes used (Dissanayake et al. 2009) and the type of energy mix used.

Moreover, typical environmental drawbacks for natural fibres composites have been related to agricultural activities. Eutrophication, freshwater ecotoxicity and land use, for example, are among the reported impacts in which synthetic fibres outperform natural ones (Duflou et al. 2014; Le Duigou and Baley 2014; Deng et al. 2016). In this case, the production of nitrogen fertilizers and zinc amendments to soil are the main causes of the environmental impacts caused by the cultivation of flax.

An important aspect covered by this study, is the consequential approach with which the LCA was carried out. By taking into consideration the fate of co-products and the land use change induced by an increased demand for flax stems, the environmental performance of the flax fibre technical textile was affected both positively through induced processes (marine eutrophication) and negatively through avoided impacts (particulate matter and photochemical ozone formation) (Gomez-Campos et al., Unpublished results).

The cradle-to-gate assessment of the biocomposite (Figure 6) and the conventional (Figure 7) panels reveal net negative impacts (avoided impacts) only in the lonizing radiation HH (Human Health) category. In both cases, the production of the hardener (methylamine) is responsible for the avoided impact; for the conventional panel, the production of the glass fibres also contributes. The methylamine and glass fibre consequential processes used for the LCA, were withdrawn from the Ecoinvent database and consider natural gas burned in co-generation power plants as the marginal source of energy. Meaning that in case of an increase in the production of methylamine and glass fibre, the consumption of natural gas will increase. This, in turn, causes a reduction in the electricity supplied from nuclear power and therefore the environmental impacts related to it, namely ionizing radiation.

Climate-wise, another expected advantage of biocomposite panels is the long-term sequestration of carbon. Carbon dioxide is taken from air by flax fibres during its growing stage (cultivation of flax) and remains "sequestrated" by it until its end-of-life. According to Le Duigou et al. (2011), $1.65 \mathrm{~kg}$ of $\mathrm{CO}_{2}$ are taken by flax for growing $1 \mathrm{~kg}$ of flax fibres (FM). This translates into almost $1250 \mathrm{~kg}$ of $\mathrm{CO}_{2}$ stored 
per $\mathrm{m}^{2}$ of flax fibre technical textile (considering a humidity content of flax of $90 \%$, a flax fibre yield of $7 \mathrm{t} / \mathrm{ha}$ and, a technical textile yield of $12 \%$ ).

Carbon sequestration is particularly relevant in the aeronautics sector as the aircrafts' materials aim to have a lifespan of 20-30 years (same as the aircraft itself). By storing carbon in such lengthy periods of time, impacts on climate change can be mitigated by delaying carbon emissions into the technosphere and giving more time for other technologies (such as direct air capture) to improve and be used as scale. This advantage, however, could not be quantified with the static LCA approach used in this study.

If the prototype biocomposite panel could be improved to attain the same mass value as the conventional one, the environmental performances of both panels would be exactly the same, over the full cradle-to-grave life cycle of the panel. However, by using the biocomposite panel, about $17 \mathrm{kt}$ of $\mathrm{CO}_{2}$ eq could be stored by airplane (by taking into consideration the characteristics of the A320neo aircraft presented in Table 5).

Considering that the worldwide commercial aviation fleet is expected to double in the next 20 years (AIRBUS 2019), the use of bio-based materials could contribute to delay the emission of over $675 \mathrm{Mt}$ of $\mathrm{CO}_{2}$ eq. This number is a rough estimation based on the work herein presented and assuming that the interior design elements of the aircraft are entirely made from the biocomposite materials. Moreover, supply would have to be assured and an evaluation should be made on whether or not flax fibre alone could cover the demand of such market, including the environmental burdens related to it. Nonetheless, it represents a real opportunity for bio-based materials, conditional to achieving weight reductions by using the biocomposite panels.

The work herein presented is based upon the development of one specific prototype, and uncovered many of the technical challenges to be solved in order to ensure a real weight reduction of bio-based panels in the aeronautic sector, which in turns governs the overall environmental performance of these panels in comparison to their conventional counterparts. The conventional panels benefited from years of optimization and refinement; while the bio-based panels are relatively newcomers. This also explains why there is a limited amount of studies to compare our results with. The most notable attempt to document the environmental impacts of bio-based materials in the aeronautics sector is the work of (Vidal et al. 2018) where different panels are evaluated, including one bio-based alternative. However, the bio-based panel presented only uses flax fibre reinforced composite as the core structure, while the skins remain a thermoplastic material; which differs from the biocomposite panel presented in this work and therefore a direct comparison between the environmental performance of the two of them is not possible. At the same time, results given by Vidal et al. (2018) are presented as Endpoint categories, while in this work results are given at a Midpoint level.

Our work also highlighted the stringent technical requirements of the aeronautics sector. Though beyond the cope of the present work, these strict technical requirements could eventually be questioned when it comes to panels destined as interior fittings. More moderate requirements for panels could be key in achieving additional weight reductions.

\section{CONCLUSIONS AND FUTURE PROSPECTS}

The work presented in this study uncovered that for an application of bio-based materials in aeronautics, weight is an upmost critical parameter defining the overall environmental performance. 
From a cradle-to-grave approach, there is no other parameter more important than this; the nature of raw materials has, in comparison, no incidence on the environmental performance.

In this matter, future work should be aimed towards the improvement of the fibre/resin ratio and the geometry of the biocomposite panel prototype in order to reduce its mass. Concerning the fibre/resin ratio, the use of different resins could be tested to evaluate their interaction with the flax fibres. Another possibility would involve the chemical treatment of flax fibres to improve their interaction with the resin. However, this would alter their composition and the environmental advantages of using natural fibres could be affected or lost. Further work should also focus on the improvement of the prototype, specifically on its geometry, in order to attain lower mass values, which would translate in a reduction of the environmental impact of the biocomposite panel. This would also imply a verification of the presented LCA in order to effectively represent the production process, if any changes were to have place.

Overall, from a cradle-to-gate approach, the biocomposite panel was shown to be more environmentally competitive than the conventional panel in the impact categories of climate change and marine eutrophication, by $34 \%$ and $30 \%$, respectively. Yet climate change gains are fictitious if the lifespan of the panel is short, as the stored carbon will be released into the atmosphere at the end of the panel's life. The processes identified as responsible for the overall environmental impacts of the panels are essentially linked to the procurement of raw materials. Agricultural activities (such as zinc amendments to soil treatment and fertilizer production) are the main processes responsible for the higher environmental impact of the biocomposite panel when compared to the conventional one. The valorisation of co-products, on the other hand, affects both positively and negatively the environmental performance of the bio-based panels and must not be neglected from the system boundary.

Given that materials in the aviation sector have a lifespan of 30 years and over, a biocomposite panel represents a relevant option when it comes to climate change mitigation. It was calculated that through the use of bio-based panels as elements in interior fittings in airplanes for the next potential as through their application as interior design elements in airplanes for the next 20 years, the emission of over 75 megatons of $\mathrm{CO}_{2}$ could be delayed. However, production processes and regulations are yet to be optimized and adjusted for biocomposite materials to have a place in the aviation sector.

\section{FUNDING}

The work was carried out as part of the doctoral thesis of A. Gomez-Campos, her work being financed by a scholarship awarded by the French Ministry of Higher Education, Research and Innovation (Ministère de l'Enseignement supérieur, de la Recherche et de l'Innovation in French).

The contribution from L. Hamelin was funded within the framework of the research project Cambioscop (https://cambioscop.cnrs.fr), partly financed by the French National Research Agency, Programme Investissement d'Avenir (ANR-17-MGPA-0006) and Region Occitanie (18015981). 


\section{REFERENCES}

ACARE. 2011. "Flightpath 2050 - Europe's Vision for Aviation - Report of the High Level Group on Aviation Research." European Comission.

ADEME. 2018. "Les déchets dangereux - Généralités et réglementation." Agence de l'Environnement et de la Maîtrise de l'Energie. 2018. https://www.ademe.fr/expertises/dechets/quoi-parlet/types-dechets/dossier/dechets-dangereux/generalites-reglementation.

AIRBUS. 2019. "Airbus Forecasts Need for over 39,000 New Aircraft in the next 20 Years." https://www.airbus.com/aircraft/market/global-market-forecast.html.

Bachmann, Jens, Carme Hidalgo, and Stéphanie Bricout. 2017. "Environmental Analysis of Innovative Sustainable Composites with Potential Use in Aviation Sector-A Life Cycle Assessment Review." Science China Technological Sciences 60 (9): 1301-17. https://doi.org/10.1007/s11431-016-9094-y.

Barth, Martha, and Michael Carus. 2015. "Carbon Footprint and Sustainability of Different Natural Fibres for Biocomposites and Insulation Material." nova-Institut GmbH.

Brandão, Miguel, Michael Martin, Annette Cowie, Lorie Hamelin, and Alessandra Zamagni. 2017. Consequential Life Cycle Assessment: What, How, and Why?

C.E.L.C. 2020. "Le Lin et Le Chanvre Européen." Secteurs d'application. 2020. http://europeanflax.com/eng/technique/19-secteurs-d-application.

Deng, Yelin, Dimos Paraskevas, Yajun Tian, Karel Van Acker, Wim Dewulf, and Joost R. Duflou. 2016. "Life Cycle Assessment of Flax-Fibre Reinforced Epoxidized Linseed Oil Composite with a Flame Retardant for Electronic Applications." Journal of Cleaner Production 133 (October): 427-38. https://doi.org/10.1016/j.jclepro.2016.05.172.

Deng, Yelin, and Yajun Tian. 2015. "Assessing the Environmental Impact of Flax Fibre Reinforced Polymer Composite from a Consequential Life Cycle Assessment Perspective." Sustainability 7 (9): 11462-83. https://doi.org/10.3390/su70911462.

Dissanayake, Nilmini P. J., J. Summerscales, S. M. Grove, and M. M. Singh. 2009. "Energy Use in the Production of Flax Fiber for the Reinforcement of Composites." Journal of Natural Fibers 6 (4): 331-46. https://doi.org/10.1080/15440470903345784.

Duflou, Joost R., Deng Yelin, Karel Van Acker, and Wim Dewulf. 2014. "Comparative Impact Assessment for Flax Fibre versus Conventional Glass Fibre Reinforced Composites: Are BioBased Reinforcement Materials the Way to Go?" CIRP Annals 63 (1): 45-48. https://doi.org/10.1016/j.cirp.2014.03.061.

Earles, J. Mason, and Anthony Halog. 2011. "Consequential Life Cycle Assessment: A Review." The International Journal of Life Cycle Assessment 16 (5): 445-53.

EC. 2013. "Commission Recommendation of 9 April 2013 on the Use of Common Methods to Measure and Communicate the Life Cycle Environmental Performance of Products and Organisations."

- - . 2017. "PEFCR Guidance Document - Guidance for the Development of Product Environmental Footprint Category Rules (PEFCRs), Version 6.3."

- - . 2018. "Periodic Reporting for Period 1 - BIOPANELS (Biocomposite Panels for Transportation) - Report Summary." 2018. https://cordis.europa.eu/project/id/782890/reporting.

- - . 2020. "European Platform on Life Cycle Assessment." European Comission Service Site. 2020. https://eplca.jrc.ec.europa.eu/EnviromentalFootprint.html.

Faruk, Omar, Andrzej K. Bledzki, Hans-Peter Fink, and Mohini Sain. 2012. "Biocomposites Reinforced with Natural Fibers: 2000-2010." Progress in Polymer Science, Topical Issue on Polymeric Biomaterials, 37 (11): 1552-96. https://doi.org/10.1016/j.progpolymsci.2012.04.003.

Fernando, Ana Luisa, Maria Paula Duarte, Anna Vatsanidou, and Efi Alexopoulou. 2015.

"Environmental Aspects of Fiber Crops Cultivation and Use." Industrial Crops and Products 68 (June): 105-15.

Graver, Brandon, Kevin Zhang, and Dan Rutherford. 2019. "CO2 Emissions from Commercial Aviation, 2018," September, 13. 
Hamelin, Lorie. 2013. "Carbon Management and Environmental Consequences of Agricultural Biomass in a Danish Renewable Energy Strategy." PhD Thesis, Odense, Denmark: University of Southern Denmark.

Hristian, L, M M Ostafe, L R Manea, and A L Leon. 2016. "The Study about the Use of the Natural Fibres in Composite Materials." IOP Conference Series: Materials Science and Engineering 145 (August): 032004. https://doi.org/10.1088/1757-899X/145/3/032004.

IATA. 2019. "Fuel." June 2019. https://www.iata.org/whatwedo/ops-infra/fuel/pages/index.aspx.

IPCC. 1999. "Aviation and the Global Atmosphere - Summary for Policymakers." San Jose, Costa Rica. https://www.ipcc.ch/site/assets/uploads/2018/03/av-en-1.pdf.

- - . 2013. "Climate Change 2013 The Physical Science Basis - Working Group I Contribution to the Fifth Assessment Report of the Intergovernmental Panel on Climate Change." https://www.ipcc.ch/site/assets/uploads/2018/02/WG1AR5_all_final.pdf.

- - . 2018. "Global Warming of $1.5^{\circ} \mathrm{C}$ - An IPCC Special Report on the Impacts of Global Warming of $1.5^{\circ} \mathrm{C}$ above Pre-Industrial Levels and Related Global Greenhouse Gas Emission Pathways, in the Context of Strengthening the Global Response to the Threat of Climate Change, Sustainable Development, and Efforts to Eradicate Poverty. [Masson-Delmotte, V., P. Zhai, H.-O. Pörtner, D. Roberts, J. Skea, P.R. Shukla, A. Pirani, W. Moufouma-Okia, C. Péan, R. Pidcock, S. Connors, J.B.R. Matthews, Y. Chen, X. Zhou, M.I. Gomis, E. Lonnoy, T. Maycock, M. Tignor, and T. Waterfield (Eds.)]. In Press." https://www.ipcc.ch/sr15/.

Joshi, S. V, L. T Drzal, A. K Mohanty, and S Arora. 2004. "Are Natural Fiber Composites Environmentally Superior to Glass Fiber Reinforced Composites?" Composites Part A: Applied Science and Manufacturing, AIChE 2002, 35 (3): 371-76. https://doi.org/10.1016/j.compositesa.2003.09.016.

JRC. 2011. ILCD Handbook: Recommendations for Life Cycle Impact Assessment in the European Context. Luxembourg: Publications Office.

Le Duigou, Antoine, and Christophe Baley. 2014. "Coupled Micromechanical Analysis and Life Cycle Assessment as an Integrated Tool for Natural Fibre Composites Development." Journal of Cleaner Production 83 (November): 61-69. https://doi.org/10.1016/j.jclepro.2014.07.027.

Le Duigou, Antoine, Peter Davies, and Christophe Baley. 2011. "Environmental Impact Analysis of the Production of Flax to Be Used as Composite Material Reinforcement." Journal of Biobased Materials and Bioenergy 5: 1-13.

Maibach, Markus, Daniel Peter, and Benno Seiler. 1999. Ökoinventar Transporte : Grundlagen Für Den Ökologischen Vergleich von Transportsystemen Und Den Einbezug von Transportsystemen in Ökobilanzen. 2nd ed. Zürich: Infras.

Mohammed, Layth, M. N. M. Ansari, Grace Pua, Mohammad Jawaid, and M. Saiful Islam. 2015. "A Review on Natural Fiber Reinforced Polymer Composite and Its Applications." International Journal of Polymer Science 2015: 1-15. https://doi.org/10.1155/2015/243947.

Morton-Jones, David H., and John W. Ellis. 1986. "'Fiberlam' Aircraft Flooring." In Polymer Products: Design, Materials and Processing, edited by David H. Morton-Jones and John W. Ellis, 21120. Dordrecht: Springer Netherlands. https://doi.org/10.1007/978-94-009-4101-4_19.

Peças, Paulo, Hugo Carvalho, Hafiz Salman, and Marco Leite. 2018. "Natural Fibre Composites and Their Applications: A Review." Journal of Composites Science 2 (4): 66. https://doi.org/10.3390/jcs2040066.

Sanjay, M.R., P. Madhu, Mohammad Jawaid, P. Senthamaraikannan, S. Senthil, and S. Pradeep. 2018. "Characterization and Properties of Natural Fiber Polymer Composites: A Comprehensive Review." Journal of Cleaner Production 172 (January): 566-81. https://doi.org/10.1016/j.jclepro.2017.10.101.

SAS. 2019. "New Aircraft and Fleet | SAS." August 1, 2019. https://www.sasgroup.net/about-sas/thefleet/airbus-a319-a320-a320neo-a321/.

Ticoalu, A, T Aravinthan, and F Cardona. 2010. "A Review of Current Development in Natural Fiber Composites for Structural and Infrastructure Applications." In , 5. Toowoomba, Australia. 
Vidal, Rosario, Enrique Moliner, Pedro P. Martin, Sergio Fita, Maik Wonneberger, Eva Verdejo, François Vanfleteren, Nieves Lapeña, and Ana González. 2018. "Life Cycle Assessment of Novel Aircraft Interior Panels Made from Renewable or Recyclable Polymers with Natural Fiber Reinforcements and Non-Halogenated Flame Retardants: LCA of Novel Aircraft Interior Panels." Journal of Industrial Ecology 22 (1): 132-44. https://doi.org/10.1111/jiec.12544.

Vieira, Darli Rodrigues, and Alencar Bravo. 2016. "Life Cycle Carbon Emissions Assessment Using an Eco-Demonstrator Aircraft: The Case of an Ecological Wing Design." Journal of Cleaner Production 124 (June): 246-57. https://doi.org/10.1016/j.jclepro.2016.02.089.

Weidema, Bo P., Massimo Pizzol, Jannick Schmidt, and Greg Thoma. 2018. "Attributional or Consequential Life Cycle Assessment: A Matter of Social Responsibility." Journal of Cleaner Production 174 (February): 305-14. https://doi.org/10.1016/j.jclepro.2017.10.340.

Wilhelm, Stefan. 2018. "Life Cycle Assessment of Electricity Production from Airborne Wind Energy." In Airborne Wind Energy, edited by Roland Schmehl, 727-50. Singapore: Springer Singapore. https://doi.org/10.1007/978-981-10-1947-0_30.

Yan, Libo, Nawawi Chouw, and Krishnan Jayaraman. 2014. "Flax Fibre and Its Composites - A Review." Composites Part B: Engineering 56 (January): 296-317. https://doi.org/10.1016/j.compositesb.2013.08.014. 